\title{
Regional Archeological and Ethnographic Conference of Undergraduate and Postgraduate Students and Young Researchers in Kranoyarsk
}

\author{
Pavel V. Mandryka* \\ Siberian Federal University \\ 79 Svobodny, Krasnoyarsk, 660041, Russia
}

Received 20.11.2014, received in revised form 26.12.2014, accepted 16.01.2015

The article reports on the origins and traditions of Siberian archaeological and ethnographic conferences at the regional and national level, on the outcomes of the next fifty fourth conference held in Krasnoyarsk, at Siberian Federal University. The forum was dedicated to two important events in archeology not only for Siberia, but also for the whole Eurasia - the 130th anniversary of discovery of the Paleolith at Afontova Mountain and the 100th anniversary of the first excavations of the monuments of the Andronovo culture. The author gives a brief history of these historical events and determines the modern level of exploration of the monuments of these periods of Antiquity.

Keywords: archeology, history of discoveries, conference, Siberia, paleolith, the Adronovo culture.

Research area: history.

In March 2014 Krasnoyarsk hosted a regular LIV archaeological and ethnographic conference of undergraduate and postgraduate students and young researchers on the basis of Siberian Federal University called "Modern Problems of Ancient and Traditional Cultures of the Peoples of Eurasia" dedicated to the $130^{\text {th }}$ anniversary of the discovery of the Paleolith at Afontova Mountain and the $100^{\text {th }}$ anniversary of the first excavation of the Andronovo culture monuments. This is one of the oldest and massive annual scientific events beyond the Urals, which gathered about a hundred of undergraduate and postgraduate students from different organizations of the Volga region, the Urals, Western and Eastern Siberia, the
Altai, the Far East, the Republic of Korea and Bashkortostan.

The tradition of holding Siberian archaeological and ethnographic student conferences has more than half-century history. Throughout the years of its organization, the Conference took place in many cities of Siberia and the Far East, which hosted participants from all over the country. The tradition of Regional Archaeological Conferences (later developed into Russian conferences) was introduced in our country at the regional level. The beginning of this "movement" can be associated with "Siberian tours" organized by archeological students of Moscow Archaeological Institute including N.N. Bortvin and A.N. Lipsky. In summer they

(C) Siberian Federal University. All rights reserved

* Corresponding author E-mail address: pmandryka@yandex.ru 
organized archaeological expeditions around the country (the Urals, Siberia, the Far East), and discussed the results at joint meetings upon arrival. The history of the first official student archaeological conferences associates with the name of an outstanding Russian archaeologist Vasily Alekseevich Gorodtsov. His students organized the discussion of their research papers in 1920.

For the Ural region, this tradition was founded by O.N. Bader in 1947 during the First Ural Archaeological Meeting. Not only scientists, but also students and even three pupils presented their works there. Subsequently, in 1969 on the initiative of V.F. Gening the Ural-Volga Regional Archaeological Student Conference was organized. The Conference has been annually held in different cities of the Urals and the Volga region without interruption for nearly 45 years.

Simultaneously with the Urals region, on the initiative of the Scientific Student Society of the Department of Archaeology of Moscow State University, the first Russian student archaeological conferences were organized in Moscow. In 1950s a series of annual forums with participation of students not only from Moscow, but also from other universities of the country (Vilnius, Voronezh, Grozny, Yerevan, Izhevsk, Kiev, Petrozavodsk, Leningrad, Molotov, Moscow, Novgorod, Riga, Sverdlovsk, Stalinabad, Tartu, Tashkent, Kharkov) were held. Participants from Siberia were students of Irkutsk State University.

It is officially known that the first conference of students-archaeologists in the region of Siberia and the Far East was held in Novosibirsk in 1971 on the basis of Novosibirsk State University. The conference was held there during four years. Archaeologists of the Institute of History, Philology and Philosophy of the SB RAS and the Academician Alexei Okladnikov personally participated in organization of the conference. Starting from the fifth conference it had been conducted in other universities of Siberian cities: Irkutsk, Tomsk, Ulan-Ude, Omsk, Barnaul, Kemerovo. In 2014 RAESC is held for the seventh time in Krasnoyarsk. We picked up the baton from the Far Eastern Federal University of Vladivostok.

We can confidently say that today all the archaeologists of our country passed through the school of Regional or National student archaeological conferences. Preparation for participation in them plays an important role in generating the habit of a young researcher for constant, daily scientific activities. In fact, besides the mandatory coursework and graduate work students have to prepare research reports, organize themselves to process and systematize the field data, read the newest Russian and foreign literature, design tables and draw illustrations, i.e. to perform a huge amount of research work. This work requires responsibility, while, as a rule, the report is presented not only to his/her fellow students, but specialists-archaeologists (in fact, all the leading archaeologists in the region take part in RAESC after earning the degrees of the Candidate of Science or the Doctor of Science).

It appears appropriate to mention one more important role of the student archaeological conference in the region. It is here where interpersonal relationships between existing and future archaeologists of Siberia and the Far East, as well as the Urals, the European part of Russia and countries neighbouring with Siberia (Kazakhstan, China, Korea) are born. The tradition of RAESC has been continuously maintained by successive generations of researchers. To date, this conference, of course, has grown into a regional one, and changes have been made to its name. Originally, the conference was called "RASC" (Regional Archaeological Student Conference) and considered as a "qualifying round" in Siberia to 
participate in AASC (All-Union Archeological Student Conference), which was held at Moscow State University. Since 1986, AASC ceased its existence, and as for Siberian conference, it still exists and is held every year despite of anything. It has been successfully developing, transforming into regional archaeological and ethnographic conference by increasing the range of scientific interests in the research of young researchers-participants. RAESC is replenished by the number of involved disciplines other than archeology and ethnography: museum studies, history, culture, art, science and others are considered. The number of participants has been growing as well, and it covers a larger territory than the Siberian region. Applications for participation in the conference come from all over Russia: from Sakhalin, Magadan and finally, Kaliningrad and Kuban. Our partners from the nearest countries - Kazakhstan, Mongolia, China, Korea and Japan - occupy quite an active position as well. It seems that in the future the geography of participants will expand, while archaeological science can not be limited to separate regions, archaeological discoveries are valuable to preserve the history, culture and technology of the whole mankind.

The archaeological and ethnographic conference of undergraduate and postgraduate students and researchers conducted in 2014 in Krasnoyarsk focused on two important events in archeology for not only Siberia, but also the whole Eurasia: the $130^{\text {th }}$ anniversary of the discovery of the Paleolith at Afontova Mountain and the $100^{\text {th }}$ anniversary of the first excavation of archaeological monuments of the Andronovo culture.

Afontova Mountain as a Paleolithic monument is known to every archaeologist of the world. The Russian school textbook on the history of the Ancient world contained a photograph of the stone tools of the primitive man from Afontova
Mountain and pointed out that at this time the man tamed a dog. Few people knew though that the evidence of the latter fact the researchers have obtained from the excavations of Afontova Mountain where in different years several skulls of this "tamed wolf" were found.

Discovery of the Palaeolithic layers at Afontova Mountain in 1884 was not accidental. Sincethelate 1870san "outrageousarchaeologist", the director of the normal school, I.T. Savenkov organizes local history tours around Krasnoyarsk and collects archaeological items in many places. In 1883 , in a deep washaway near Ladeiskoe village (on the right bank of the modern city of Krasnoyarsk), along with the bone of a primitive bull he finds a Paleolithic stone tool with "rough lining, tongue-shape forms ... similar to the Sep-Acheulian and Mousterian types of tools". This discovery fueled Savenkov's confidence in the possibility of discovering the Paleolith on the Yenisei. Next summer, in 1884, during the first visit of the brick factory pits at Afontova Mountain he collects stone tools, fragments of animal bones at different heights along the slope. Collecting from different locations at the Mountain continued in the subsequent years (until 1893). However, only after these places were visited by the invited reputable Siberian researchers - a mining engineer I.A. Lopatin, a researcher, a public figure and a writer N.M. Iadrintsev and a geologist I. D. Chersky Savenkov's assumption of the Quaternary loess, and hence, the Paleolithic age of the findings was finally approved. In 1892, Savenkov reported his assumptions regarding the age of the findings from Afontova Mountain at the International Anthropological Congress in Moscow and found support for his views from a French archaeologist, baron Joseph de Baye. On his return from long "trips" to Warsaw and Minusinsk to Krasnoyarsk in 1914, Savenkov develops an extensive programme of research 
of Afontova Mountain and in summer he begins to conduct methodical excavations that he organized. However, on the $1^{\text {st }}$ of September of the same year, he died before he could complete his plan. Savenkov was buried in Krasnoyarsk Trinity cemetery at Pokrovskaia Hill.

The history of research at Afontova Mountain as an archaeological site enlists many researchers. In 1912, tools and fauna is collected by A.N. Sobolev, simultaneously the fauna is studied by a young schoolboy V.I. Gromov. In 1919, N.K. Auerbach and G.P. Sosnovsky carry out exploration works at the site. In 1920, an Austrian archaeologist G. Merhart joined them accepted for service at the museum at this time. Later, from 1923 to 1925, N. Auerbach, G.P. Sosnovsky and V.I. Gromov organized wide-spread excavations in the area near Iudin's dacha (Afontova Mountain II) and at the site of Savenkov's excavations near petroleum storage (Afontova Mountain III). They involved young Krasnoyarsk citizens to their excavations, school tours for children of the city were organized to the site. In 1924, the country's leading archaeologist V.A. Gorodtsov visited these excavations and highly praised the results of the work. In 1930, N.K. Auerbach conducts his last research at Afontova Mountain. Then exploration is carried out by G.P. Sosnovsky, and in 1933 V.I. Gromov discovers a new site at Afontova Mountain II. In 1937 he organized a tour to Afontova Mountain for the participants of the XVII International Geological Congress and during the tour a French delegate Fromagier found a part of a human skull from the cultural layer. In 1940, the last excavations at Afontova Mountain were performed by G.P. Sosnovsky. Later on, Krasnoyarsk Regional Local Lore Museum will receive some Neolithic tools, including the materials from Neolithic burials, which were published by A.P. Okladnikov and N.P. Makarov. After G.P. Sosnovsky's work no further excavations of the Paleolithic layers on
Afontova Mountain were organized up to the archaeological 1990s. Only S.N. Astakhov carried out some insignificant stripping at separate sections summarizing the data for his dissertation research. In 1992, 1995, 1996, and since 2001 E.V. Artem'ev has been organizing systematic excavations here. In 2014, in connection with the construction of the fourth bridge over the Yenisei River, extensive excavations were organized by the Institute of Archaeology and Ethnography of the SB RAS (Novosibirsk), together with the Krasnoyarsk colleagues. A large conference was held on the $100^{\text {th }}$ anniversary of the discovery of the Paleolith on the Yenisei in Krasnoyarsk in 1984, the participants of which established a memorial plaque in honour of the discoverer of the Paleolith at Afontova Mountain I.T. Savenkov.

Materials from Afontova Mountain and their interpretation occupy a worthy place in the analysis of the views on the Paleolith of Siberia, which is given in generalizing works by G.P. Sosnovsky, G. Merhart, V.E. Larichev, S.N. Astakhov, Z.A. Abramova, S.M. Zeitlin, S.A. Vasil'ev and other researchers. It is no coincidence that research materials from Afontova Mountain served as a model for allocating the Afontova archaeological culture of the late Paleolithic of Siberia.

Year 2014 is remarkable for the $100^{\text {th }}$ anniversary of the first archaeological excavations of the Andronovo cemetery, which marked the beginning of research and identification of the Andronovo culture. The Andronovo monuments are known today across the steppe and partly the forest-steppe zone of the Urals and Kazakhstan, Western Siberia and Altai foothills, as well as in the northern part of the Minusinsk Hollow. Discovery of the first monuments occurred on the very eastern edge of the Andronovo tribes settlement, and therefore it has got the name of one of them, located near the Siberian village 
Andronovo in Nazarovskaia Hollow. Discovery of the later is associated with the rescue works at the construction site of the railway Achinsk Minusinsk.

The first monument of this culture was discovered in 1913, when the assistant of the Krasnoyarsk Regional Local Lore Museum conservator Aleksander P. Ermolaev excavated several graves on the left bank of the Yenisei near the village Baten' in the area of Iarka. In 1914, Arkady Tugarinov and Sergei Sergeev organized exploration in the area of construction of the railway Achinsk - Minusinsk. It was at that time, when Tugarinov excavates the burial destroyed by the railway near the Andronovo village on the left bank of the river Serezh. After 12 years, the results of the works were presented in his article "Andronovo Graves" and published in the journal "Siberian Live Antiquity" published in Irkutsk (1926). Thanks to the rescue works three fences were dug out and things were collected from the other two destroyed during the construction of the railway bridge.

For the first time the originality of these findings was pointed out by G. Merhart, and their cultural independence was determined by S.A. Teploukhov (announcing it in 1921-1922 at the board of Krasnoyarsk Regional Local Lore Museum, and first publishing the materials in 1922), who excavated graves at several cemeteries of the Yenisei and compared the materials (mainly ceramics) from the Andronovo burial with others, especially with the materials from the cemetery near Novoselo washed away by the Yenisei, with a few vessels that S.M. Sergeev and I.A. Pikulevich managed to collect. Following S.A. Teploukhov, large excavations near Ulus Orak were organized in 1925-1928 by G.P. Sosnovsky, who studied 47 graves, surrounded by fences. In 1930-1931 individual Andronovo graves were studied by S.V. Kiselev and V.P. Levasheva. Culture studies were performed by an archaeologist K.V. Salnikov, who in 1948 offered the first classification of the monuments. S.V. Kiselev summarized the data regarding this Yenisei archaeological culture in a special section of the monograph published in 1949 and republished in 1951. More significant works with the monuments related to the Andronovo culture were carried out in 1950-1970s by A.I. Martynov, N.L. Chlenova, M.G. Elkin, N.V. Nashchokin, M.P. Griaznov, N.V. Leontiev and G.A. Maksimenkov. The latter prepared a summarizing monograph on the Andronovo culture on the Yenisei River (1978), which still has not lost its relevance. Generalization of the Andronovo antiquities in different regions of Western Siberia can be found in the analytical work by V.I. Matiushchenko (1973), M.F. Kosarev (1981) and V.I. Molodin (1985, 2008). In the 1980s, excavations at the sites of the Andronovo culture in Western Siberia and Minusinsk Hollow were conducted by A.I. Martynov, S.B. Gul'tov, Vladimir Bobrov, A.M. Kulemzin, V.A. Zakh, Iu.I. Mikhailov, I.V. Kovtun and other researchers. In the Altai the monuments of this culture were studied by M.P. Griaznov, S.M. Sergeev, V.A. Mogil'nikov, Iu.F. Kiriushin, V.B. Borodayev, A.P. Umansky, A.B. Shamshin, A.L. Kungurov, A.A. Tishkin, S.M. Sitnikov, S.P. Grushin and other researchers.

LIV RAESC took place in March 2014 and began with scientific reports about the discovery of the Paleolith at Afontova Mountain in Krasnoyarsk (Doctor of History, professor N.I. Drozdov) and the history of archaeological research performed by the staff of the Krasnoyarsk Regional Local Lore Museum (Candidate of History N.P. Makarov). On the first day, the exhibition "Antiquities of the Taiga Region" dedicated to the change of the material culture of the ancient inhabitants in the southern taiga zone from the Neolithic to the late Middle Ages was opened. In the University Library building 
the exhibits found by the SibFU archaeological expedition in the North and the Lower Angara region, the middle Yenisei were demonstrated.

Leading experts, employees of Siberian universities and academic institutions of the SB RAS and local lore museums were invited to the conference. There were 8 sections at the Conference: historiography, interdisciplinary research and methodology of archeology, Stone Age, Bronze Age and early Iron Age, the Middle Ages, primitive art, museum studies and protection of cultural heritage, anthropology and ethnoarcheology.

92 reports were presented during the conference. The reports of the participants touched on various topics of modern science. They were devoted to the history of archaeological organizations development and the formation of scientific schools, the results of natural science research, application of new GIS and computer technology, the culture of work in the field teams, the technology of manufacturing ancient ceramic vessels and stone tools, their interpretations and cultural identity. A number of sections examined a wide range of issues related to the study of ancient house construction, ritual complexes and objects, material culture and ritual practices of the peoples of Eurasia, with preservation of petroglyphs in the natural environment, using methods museumification of archaeological monuments, specificity of urban archeology and legal aspects of preserving the objects of archaeological heritage. The reports on the typology of weapons and ornaments, as well as comprehensive study of individual Medieval objects and cultures arouse significant interest. Modern ethnic processes in Siberia and the Far East were not neglected neither.

At the conference, leading experts in the field of archeology and ethnography conducted six workshops: "The Andronovo Culture: Contemporary Issues" (Doctor of History
V.V. Bobrov); "The Study of Small Indigenous Peoples of the World" (Doctor of History V.P. Krivonogov); "Dendrochronological Research in Archeology and History" (Doctor of History V.S. Myglan); "On the Methods of Studying Petroglyphs" (Candidate of History A.L. Zaika); "Research of Objects of Bone Carving of the Paleometal Age" (Doctor of History A.P. Borodovsky); "Graphic Reconstruction of Weapons According to Archeological Findings" (Doctor of History Iu.S. Khudiakov).

There was a heated discussion at the round table "The Mission of the University Museums of Archaeology and Ethnography". It was attended by leading archaeologists and anthropologists from universities of Siberia and the Far East, representatives of state authorities on the protection of cultural heritage and museum principals. The outcome of the round-table discussion was the focus on the mechanism of university museums inclusion in the State Museum Fund, as well as the idea of establishing a research and educational museum archeological centre within the walls of Siberian Federal University.

It is noteworthy that the LIV Regional (X All-Russian with international participation) archaeological and ethnographic conference of undergraduate and postgraduate students and young researchers was held with the active support of young professionals, candidates and doctors of sciences. They worked at the conference sections, entered into discussions with undergraduate and postgraduate students, conducted master classes, raising fundamental problems of science and explaining the intricacies of the modern scientific methods application. The participants of the Conference praised the publication of the collection of abstracts, increased scientific level of a significant part of the reports on the topical issues of theory, methods and practice of archeology, anthropology, ethnology and museum 
studies. Young researchers paid special attention to the problem of preservation of historical and cultural heritage and outlined the necessity to create a state program for preservation of the objects of archaeological heritage through their museumification.
This issue of the Journal includes some scientific developments of undergraduate and postgraduate students and young researchers, whose reports on the outcomes of the conference were considered to be "the best".

\section{Региональная археолого-этнографическая конференция студентов, аспирантов \\ и молодых ученых в Красноярске}

П.В. Мандрыка

Сибирский федеральный университет Россия, 660041, Красноярск, пр. Свободныий, 79

В статье сообщается об истоках зарождения и традиция проведения в Сибири археологоэтнографических конференщий регионального и российского уровня, об итогах работь очередной, пятьдесят четвертой конференции, которая прошла в Красноярске в Сибирском федеральном университете. Форум был посвящен двум важным событиям в археологии не только Сибири, но и всей Евразии - 130-летию открытия палеолита на Афонтовой горе и 100-летию первых раскопок памятников андроновской культуры. Автор приводит краткую историю этих исторических событий и обозначает современную степень изученности памятников этих периодов древности.

Ключевые слова: археология, история открытий, конференция, Сибирь, палеолит, андроновская культура.

Научная спещиальность: 07.00.00 - исторические науки. 